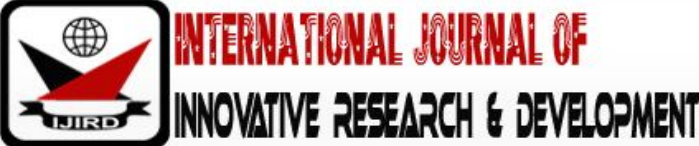

ISSN 2278 - 0211 (Online)

\section{The Relationship between Teachers' ICT Knowledge and Availability of ICT Facilities in the Junior High Schools: A Case Study in the Savulugu District in the Northern Region of Ghana}

\begin{tabular}{c} 
Abu Sulemana \\
Tutor, Department of Mathematics \& ICT, Al-Faruq College of Education, Ghana \\
Victor King Anyanful \\
Tutor, Department of Mathematics \& ICT, OLA College of Education, Ghana \\
Issah Balah Abdulai \\
Tutor, Department of Mathematics \& ICT, Kibi Presbyterian College of Education, Ghana \\
\hline
\end{tabular}

\begin{abstract}
:
Several variables make ICT integration with the teaching and learning processes much easy. These variables include teachers' attitude, teachers' knowledge, facilities available and motivation. This study examined the relationship between Teachers' ICT knowledge and availability of ICT facilities in the Junior High Schools in the Savulugu District in the Northern Region of Ghana. Correlation design was used for the study. The correlation levels between these variables were measured through the data gathered by the use of a four-point Likert type scale. The targeted population was the Junior High School teachers in the said district. A total of 68 questionnaires were retrieved and analyzed. The research findings indicated a low Junior High School Teachers' ICT knowledge in the district (mean $=2.48$ ) and availability of ICT facilities (mean =1.71). Besides, the research showed both correlation coefficients of Teachers' ICT knowledge and Availability of ICT facilities $(r=.656)$. Despite the moderate correlation levels, Teachers' ICT knowledge and Availability of ICT facilities need to be improved.
\end{abstract}

Keywords: ICTs, Savulugu, innovations, correlation, pedagogical content knowledge

\section{Introduction}

Information and Communications Technology has come to improve performance of activities in every sphere of life. Teaching and learning processes are enhanced through the appropriate use of Technology in our educational institutions. Every teacher training institution in the world trains teachers on how to use ICT in their schools for teaching and learning processes, and Ghana is not an exception. But research shows that this does not bring about the effectiveness and efficiencies desired by the society, since classroom teachers often claim to have changed their practice (Cuban 2001).

Besides, integrating ICTs in the teaching and learning processes challenges teachers, hence, more innovative skills are needed to know, understand and apply ICTs correctly (Olson 2000). The knowledge in the use of ICTs is not enough, if the facilities are not available or the facilities are inadequate. The government of Ghana has the commitment to extend computers to all schools in the country. Also, commitment to promote equal distribution of ICT facilities in the school system to enable all teachers and students benefit from ICT regardless of their geographical location (Mfum-Mensah, 2003). This implementation would be a great achievement in the educational system. Availability of ICT facilities promote effective teaching and learning in all disciplines.

Computer training is limited to the urban areas in the country. Selected schools in rural areas have attempted to compete with their urban counterparts through the engagement of private companies and non-governmental organizations to provide the needed computer training. Privately owned computer training institutions charge relatively high fees hence most students find it difficult to acquire such important knowledge and skills to learn ICT (Parthenope, 2003)

The Colleges of Education in Ghana curricula requires that teachers integrate ICT into instruction throughout the curriculum. However, research shows that the Colleges of Education are not doing enough to equip student teachers with requisite skills to integrate ICT into teaching and learning processes during their initial training. Additionally, the teacher training universities, University of Cape Coast and University of Education, Winneba are not training the student teachers enough to acquire the ICT knowledge needed for the competitive world (Mereku, Yidana, Hordzi, Tete-Mensah, Tete-Mensah, and Williams, 2009). 
Furthermore, teachers who employ ICT tools regularly in their teaching and learning processes develop the required skills and knowledge and, therefore, become confident in the use of ICTs (Cox, Preston and Cox, 1999). Also, teachers who own computers at home have less or no fear in using computers for teaching and learning processes (Guha, 2000).

\section{Material and Methods}

This study investigated the relationship between Teachers' ICT knowledge and Availability of ICT facilities for effective use of ICT tools in the teaching and learning processes. The design used for the study was correlation. It examines the relationships between these psychological quantities (Mark, 2004). Also, correlation research normally takes place outside the laboratory, as a result of this, it turns to be more applicable to every day situation. Besides, it creates room for further research work to be done by others, this is because it provides a good starting point. The target population was the Junior High School teachers in Savulugu in the Northern Region of Ghana. The convenience sampling technique, a non-probability method was employed. Available Junior High School teachers who agreed to take part were used for the study. A total of 75 teachers were sampled, however, 68 teachers returned their completed questionnaire.

The main instrument used for this study was questionnaire. A four-point Likert scale was used starting from strongly agreed (coded-4) to strongly disagreed (coded-1). The questionnaire items were administered to respondents to indicate the level at which they agreed or disagreed to the 4-point Likert scale type questionnaire. The 68 questionnaires returned were edited and serially numbered for easy analysis. Likert scale is the most suitable instrument for examining respondent's views regarding usage of tools (Dumas, 1999).

\subsection{Theory}

Integration of technology into the teaching and learning processes has added complexity to the fundamental knowledge of what constitute the teachers' professional knowledge base (Mishra \& Koelher, 2006). The Technological knowledge is made up of an understanding of the standard technologies like books, chalk and advanced technologies like the internet, software and hardware. Also, pedagogical knowledge for the use of technologies in teaching and learning process is required, (Mishra and Koehler, 2006). They added that teachers need to be exposed to a lot of activities through the use of available facilities in lesson planning and how to appropriately use these facilities in their lessons for effective teaching and learning to take place.

\subsection{Calculation}

There are many methods used in measuring internal consistency of questionnaires. These include the KuderRichardson, Cronbach alpha, parallel, strict parallel and split-half methods. But the Cronbach alpha was used since it is a general form to determine consistency. McMillan and Schumacher (2006) it is very good for statements that are neither correct nor incorrect. The Cronbach alpha's $\alpha$-coefficient was calculated with the SPSS version 20.0. A data analysis computer program. According to George and Mallery (2003) an acceptable range of reliability of the coefficient for instruments should be between .70 and .90. The Cronbach alpha's $\alpha$-coefficient of the instrument was .840 .

Construct validity was calculated by the use of the Kaiser-Meyer-Olkin measure of sampling adequacy (KMO). The $\mathrm{KMO}$ can be calculated for individual and multiple variables and represents the ratio of the squared correlation between variables to the squared partial correlation between variables. The KMO statistics varies between 0 and 1 (Field, 2005). In this study, the KMO value was .80 suggesting the adequacy of the sample size for the factor analysis was obtained. Besides, the Bartlett's test of sphericity was significant suggesting that the sample was not an identity matrix. The KMO and Bartlett's measure are used to measure sampling adequacy and non-identity matrix of the sample in the use of factor analysis (2005b). The KMO and Bartlett's test of sphericity are shown in Table 1.

\begin{tabular}{|cc|}
\hline Kaiser-Meyer-Olkin Adequacy Measure of Sampling & $\mathbf{. 8 0 0}$ \\
\hline Bartlett's Test of Sphericity Approx. Chi-Square & $1.964 \mathrm{E} 3$ \\
$\mathrm{df}$ & 378 \\
$\mathrm{dig}$ & .000 \\
& \\
\hline
\end{tabular}

Table 1: Kaiser-Meyer-Olkin and Bartlett's Test

\section{Results and Discussion}

Descriptive statistics such as mean and standard deviation were used to find out Teachers' ICT Knowledge and Available ICT faculties in the said district. Besides, the study employed a bivariate correlation to measure the extent of the relationships between Teachers' ICT Knowledge and Available ICT faculties. Pearson's product-moment correlation coefficient was calculated for the bivariate correlation analysis. The correlation coefficient squared (R2) was used for a good interpretation of the relationship to be obtained. $\mathrm{R} 2$ is a measure of the amount of variability in one variable that is explained by another (Field, 2005).

The results of the descriptive statistics indicate low levels of Teachers' ICT Knowledge and Available ICT facilities in the district as 2.48 and 1.71 respectively. Table 2 shows the means and standard deviations for the two variables. 


\begin{tabular}{|c|c|c|}
\hline & Mean TK & Mean AF \\
\hline Valid & 68 & 68 \\
\hline N Missing & 0 & 0 \\
\hline Mean & 2.48 & 1.71 \\
\hline Std. Deviation & .605 & .586 \\
\hline
\end{tabular}

Table 2: The Mean and Standard Deviation

TK=Teachers' Knowledge, AF = Availability of Facilities

\subsection{Correlation Analysis}

Table 3 shows the correlation analysis between the Teachers' ICT Knowledge and Available ICT faculties

\begin{tabular}{|c|c|c|c|}
\hline \multicolumn{2}{|c|}{} & $\begin{array}{c}\text { Teachers' ICT } \\
\text { Knowledge }\end{array}$ & $\begin{array}{c}\text { Available ICT } \\
\text { Faculties }\end{array}$ \\
\hline \multirow{2}{*}{$\begin{array}{c}\text { Teachers' ICT } \\
\text { Knowledge }\end{array}$} & Pearson Correlation & $.656^{* *}$ & 1.000 \\
\cline { 2 - 4 } & Sig. (2-tailed) & .000 & 68 \\
\cline { 2 - 4 } & $\mathrm{N}$ & 68 & $.656^{* *}$ \\
\hline \multirow{2}{*}{$\begin{array}{c}\text { Available ICT } \\
\text { faculties }\end{array}$} & Pearson Correlation & 1.000 & .000 \\
\cline { 2 - 4 } & Sig. (2-tailed) & 68 & 68 \\
\hline
\end{tabular}

Table 3: Correlations

** Correlation Is Significant at the 0.01 Level (2-Tailed)

\subsection{The Relationship between Teachers' ICT Knowledge and Available ICT Facilities}

The result obtained in Table 3 says that Teachers' ICT Knowledge is positively correlated to Available ICT facilities ICT (0.656, $\mathrm{p}<0.05)$. The relationship is significant at the level 0.01 level. The value 0.656 indicates that the correlation is high. By using the principal of $\mathrm{R}^{2}, \mathrm{R}^{2}$ is $0.43(0.6562)$. Considering the $\mathrm{R}^{2}$ value, it can be concluded that Teacher's ICT Knowledge explains 43 percent of the variability in teacher's ICT knowledge and available ICT facilities.

The results show that Savulugu teachers have moderate ICT knowledge. The implication is that, the teachers are able to use some of the ICT tools like, word processing, spreadsheet presentation software and multimedia software in their teaching and learning processes. Besides, the results indicated moderate available ICT facilities in the schools that can enhance teaching and learning. Additionally, there is positive relationship between Teachers' ICT knowledge and available ICT facilities. Teachers ICT knowledge will be useful if the facilities are available, vice versa. Finally, the results seem to support the research findings that available ICT facilities enhances knowledge (Cox, Preston and Cox, 1999).

\section{Conclusion}

The findings indicated a correlation between Teachers' ICT knowledge and available ICT facilities in the Junior $\underline{\text { High }}$ Schools in Savulugu. The teachers need additional training to enable them integrate ICT into various subjects easily. Therefore, availability of ICT facilities promotes the acquisition of ICT knowledge.

\section{References}

i. Cox, M., Preston, C., \& Cox, C. (1999). What factors support or prevent teachers from using ICT in the primary classroom. Paper presented at the British Educational Research Association Annual Conference. Universe Sussex at Brighton. (September 2-5 1999).

ii. Cuban. L., (2001) Oversold and underused: Computers in the Classroom (Cambridge: Harvard University Press).

iii. Dumas, J.S. \&Redish, J.C. (1999). A Practical Guide to Usability Testing. Intellect: Portland.

iv. Field, A.P (2005a). Discovering Statistics Using SPSS for Windows, London: Sage Publications.

v. Field, A. P. (2005b). Factor Analysis Using SPSS. Theory of SPSS: Theory and Application. Retrieved February 2011, from http:/ / www.sussex.ac.uk / users/ and/ factors/ pdf

vi. George, G. \& Mallery, P. (2003). SPSS for Windows Step by Step: A Simple Guide and Reference, 11.0 Update. Allyn and Bacon: Boston, MA.

vii. Guha, S. (2000). Are we all technically prepared? Teachers' perspectives on the causes of comfort or discomfort in using computers at elementary grade teaching. Paper presented at the Annual Meeting of the National Association for the Education of Young Children Atlanta, GA.

viii. McMillan, J.H., \& Schumacher, S. (2006). Research in education: Evidence-based inquiry (6th ed.). Boston: Pearson.

ix. Mark R.L. (2004). Introduction to Behavioral Research Methodology (5th Ed.). Pearson: Boston

x. Mereku, D. K., Yidana, I, Hordzi, W., Tete-Mensah, I., Tete-Mensah, W., \& Williams, J. B. (2009). Ghana Pan-African Report. University of Education, Winneba, Ghana. 
xi. Mfum-Mensah, O. (2003). The impact of non-formal basic education programs: a case study of northern Ghana, Unpublished PhD, dissertation, University of Toronto.

xii. Mishra, P., \& Koehler, M. J. (2006). Technological pedagogical content knowledge: A framework for teacher knowledge. Teacher College Record, 108(6), 1017-1054.

xiii. Olson, J. (2000) Trojan horse or teacher's pet? Computers and the culture of the school. Journal of Curriculum Studies, $32(1), 1-8$.

xiv. Parthemore, J. (2003). A secondary school computer lab in rural Brong- Ahafo: A case study reflection on the future of secondary school computer literacy and computer-based distance education in Ghana. [Online], Available :http:/ / www.wess.edu.gh/ lab/ reports/ papers.pdf. http:/ / www.wess.edu.gh/ lab/ reports/ papers.pdf

Retrieved

May 2018,

from 